\title{
Glomerella Gummosis of Citrus Species in Puerto Rico
}

\author{
Luis A. Alvarez Garcia ${ }^{1}$
}

\section{INTRODUCTION}

Some years ago research was initiated on a serious gummosis of citron (Citrus medica L.), grapefruit (C. paradisi Macf.), sour orange (C. aurantium $\mathrm{L}_{\text {.) }}$, and orange (C. sinensis (L.) Osbeck). It was first seen as especially severe in the Isabela region, but has been found in many other areas since. The symptoms of this disease were suggestive of, but distinctly different from, the long-known and common brown rot or foot rot gummosis caused by Phytophthora citrophthora (R. E. Sm. and E. H. Sm.) Leonian.

Surveys were conducted while systematic isolations and pure culture studies were carried on, finally proving the pathogenicity of the fungi obtained, through inoculations in greenhouse-grown seedlings on 20 different Citrus species and varieties under carefully regulated conditions. This resulted in the discovery that there was one organism involved in this newer special gummosis trouble. While numerous other organisms were isolated, it was only the polymorphic fungus Glomerella cingulata (Ston.) Spauld. and Schr. (Colletotrichum gloeosporioides Penz.) that caused the characteristic gum exudation, spoken of as "teardrops" by growers. There were other pitchy and oily, cankerous lesions.

Intensive studies of field occurrence were made in the vicinities of Isabela, Adjuntas, and Jayuya, and indicated increasing severity of the trouble. It attacks both scions and grafting stocks in nurseries and groves, and has been found from 1946 to 1962 to be especially severe on the Chironja grafted unto grapefruit stock, and the grapefruit variety known as Isabela.

\section{METHODS AND FINDINGS}

The causal fungus may be a local strain of Glomerella cingulata. It was first seen in 1946 and designated as a Colletotrichum when it was causing severe damage $(1)^{2}$. It was early considered as perhaps involved in the anthracnose (1) disease complex on several hosts, when the organism from Citrus was used to inoculate Annona, causing severe disease. It has been well-known for over 40 years (2) that the classic foot rot and gummosis of Citrus is from a Phytophthora invading roots and causing disease especially notable at the soil line. This was described in detail and well illustrated

1 Former Phytopathologist, Agricultural Experiment Station, University of Puerto Rico, Río Piedras, P.R.

2 Italic numbers in parentheses refer to Literature Cited, p. 40. 
by Knorr, Suit, and DuCarme (3). However, the Glomerella gummosis is not necessarily a foot rot. It attacks through stem wounds and even causes leaf infections that then invade the petioles and enter stems where it causes pitchy lesions, and "teardrops" ooze from cankers.

It was found through laboratory and greenhouse studies that Glomerella grew well at temperatures up to $40^{\circ} \mathrm{C}$. It produced colonies of somewhat varying appearance, although similar in gross character, differing in color from white to grayish and olivaceous, but all with spores of the Colletotrichum (imperfect) stage of Glomerella.

Artificial inoculation with isolates of the fungus on citron, grapefruit, and sour orange caused an eleoresinosis or gummosis, and pitchy canker. These symptoms also developed on common orange in the field, and isolations from them recovered the Glomerella fungus. Reisolations established the field and artifically produced disease symptoms are, as such, caused by this organism.

Inoculations were made by cutting into the bark of healthy seedlings and introducing spore suspensions into the injured tissues. These seedlings were then kept under carefully regulated conditions, and exudation of gum was developed on wounded inoculated stems at greenhouse temperatures of $24^{\circ}$ to $26^{\circ} \mathrm{C}$., with a relative humidity of 60 to 80 percent. Some grapefruit seedlings were drying at the end of 30 days after inoculation, and this was especially severe in the Isabela variety. Control seedlings with stem injuries but no fungus spores put into them, were also held under the conditions described and they healed well; healthy callus formed in the large uninoculated cuts, and there was no indication of gum or teardrop developments.

Results were different in other sets of inoculated and uninoculated seedlings in the greenhouse at a temperature range of $26^{\circ}$ to $28^{\circ} \mathrm{C}$., and at a relative humidity of 80 to 100 percent. No seedlings, either inoculated or uninoculated, became diseased, even after being held over a month under these conditions. Furthermore, those seedlings that had been inoculated, and incubated at a lower temperature, thus producing typical Glomerella gummosis, recovered from the infection when subjected to high temperatures, above $28^{\circ} \mathrm{C}$., accompanied by a relative humidity of 80 to 100 percent. Under these conditions it was of special interest that much healthy callus developed around the inactivated diseased areas, and wartlike callous growths appeared, thrusting through the cankered spots.

\section{SUMMARY}

This article deals with the results of research on a serious gummosis disease found in the Isabela region, especially attacking citron, grapefruit, sour orange, and orange. 
Further studies indicated a rapid spread of the disease in the vicinities of Isabela, Adjuntas, and Jayuya, seen now "in scions and grafting stocks in nurseries and groves" of citrus. Inoculations of the fungus on these citrus fruits proved the pathogenicity of this organism. Then accurate control methods were adopted by inoculating spore suspensions into the injured tissues and keeping these seedlings at a temperature range of $24^{\circ}$ to $26^{\circ} \mathrm{C}$. and a relative humidity of 60 to 80 percent.

Control seedlings with stem injuries, but no fungus spores inoculated into them were also held under these scientific conditions until they healed well, thus developing healthy callus around the inactivated diseased areas.

However, the "Glomerella gummosis", as it is called, is not necessarily a foot rot. It attacks through stem wounds and even causes leaf infections that then invade the petioles and enter stems where it causes pitchy lesions, and "teardrops" ooze from cankers.

\section{RESUMEN}

Esta información se refiere a los trabajos de investigación efectuados sobre una grave enfermedad de gomosis, localizada en la región de Isabela y que ataca las plantaciones de cidra, toronja, naranja agria y china.

Estudios posteriores indicaron que la enfermedad se había extendido a zonas vecinas a Adjuntas y a Jayuya, encontrándose incluso en predios experimentales de cítricas destinados a la producción de esquejes y material de injerto.

Algunas fases del experimento consistieron en cortar la corteza de algunos árboles e introducir en los tejidos afectados suspensiones de esporas, manteniéndolos a temperaturas de $24^{\circ}$ a $26^{\circ} \mathrm{C}$. y a una humedad relativa de 60 a 80 por ciento.

La enfermedad "Gomosis glomerela" ataca a través de las lesiones en el tallo, causa infecciones en la hoja que después invaden los pecíolos y el tallo entero, causando así lesiones negruzcas y una exudación anormal llamada "lágrima" cancerosa.

\section{LITERATURE CITED}

1. Alvarez-García, L. A., Anthracnose of the Annonaceae in Puerto Rico, J. Agr. Univ. P.R., 33 (1) 27-43, 1949.

2. Guiscafré, J. R., The brown rot fungus in Porto Rico, J. Agr. Univ. P.R., 16 (2) 193-202, 1932.

3. Knorr, L. C., Suit, R. F., and DuCharme, E. P., Handbook of Citrus Diseases in Florida, Univ. Fla. Agr. Exp. Sta. Bul. 587, 157 pp., 1957. 